\title{
Chemical and bromatological characteristics of elephant grass silages containing a mango by-product ${ }^{1}$
}

\author{
Margareth Maria Teles Rêgo ${ }^{2}$, José Neuman Miranda Neiva ${ }^{3}$, Aníbal Coutinho do Rêgo ${ }^{4}$, Magno \\ José Duarte Cândido ${ }^{5}$, Maria Socorro de Sousa Carneiro ${ }^{5}$, Raimundo Nonato Braga Lôbo 6 \\ ${ }_{1}$ Pesquisa financiada pelo CNPq e FUNCAP. \\ 2 Programa de Pós-Graduação em Zootecnia da Universidade Federal do Ceará. \\ 3 Universidade Federal do Tocantins. Bolsista do CNPq. \\ ${ }^{4}$ Mestrando da Universidade Federal de Lavras. \\ ${ }^{5}$ Universidade Federal do Ceará \\ ${ }^{6}$ EMBRAPA-Caprinos.
}

ABSTRACT - This study was carried out to evaluate the nutritive value of elephant grass (Pennisetum purpureum, Schum.) silages with the addition of $0,4,8,12$ and 16\% dehydrated mango (Mangifera indica, L.) by-product (DMB), on the fresh matter basis. A randomized complete design with four replications was used. As experimental silos, 210L plastic drums were used. Dry matter (DM), organic matter $(\mathrm{OM})$, crude protein $(\mathrm{CP})$, neutral detergent fiber (NDF), acid detergent fiber (ADF), hemicellulose (HCEL), ether extract (EE), total carbohydrates (TC), non-fibrous carbohydrates (NFC), neutral detergent insoluble nitrogen (NDIN, \% total $\mathrm{N}$ ), acid detergent insoluble nitrogen (ADIN, \% total N), pH values, ammoniacal nitrogen $(\%$ total $\mathrm{N})$, lactic acid, acetic acid, butyric acid and propionic acid levels were determined. The DM, OM, CP, EE, NFC, NDIN, lactic acid and propionic acid levels increased with the DMB addition while the NDF, ADF, hemicellulose, $\mathrm{N}-\mathrm{NH}_{3} / \mathrm{ammoniacal}$ nitrogen levels and the $\mathrm{pH}$ values decreased with the DMB addition. The addition of DMB had a quadratic effect on the acetic and butyric acid levels but there was no effect with the addition of DMB on TC and ADIN. The DMB can be used at the ensiling of the elephant grass, because the addition of $8.6 \%$ improves the silages fermentative process. However, these silages have low crude protein levels and high contents of ether extract and nitrogen compounds mixed with the fiber (NDIN and ADIN) in the silages, that may damage their use by animals.

Key Words: fermentation, Mangifera indica, nutritive value, Pennisetum purpureum

\section{Características bromatológicas e fermentativas de silagens de capim- elefante contendo subproduto da manga}

\begin{abstract}
RESUMO - Este trabalho foi conduzido com o objetivo de avaliar o valor nutritivo de silagens de capim-elefante (Pennisetum purpureum, Schum.) com $0 ; 4 ; 8 ; 12$ e 16\% de subproduto do processamento de manga (Mangifera indica L.) desidratado, com base na matéria natural. Utilizou-se o delineamento inteiramente casualizado com quatro repetições. Como silos experimentais, foram utilizados tambores plásticos de $210 \mathrm{~L}$. Determinaram-se os teores de nutrientes, os valores de $\mathrm{pH}$ e os teores de nitrogênio amoniacal $\left(\mathrm{N}-\mathrm{NH}_{3}, \%\right.$ do $\mathrm{N}$ total), ácido lático, acético, propiônico e butírico. Os teores de matéria seca (MS), matéria orgânica (MO), proteína bruta $(\mathrm{PB})$, extrato etéreo $(\mathrm{EE})$, carboidratos não-fibrosos (CNF), nitrogênio insolúvel em detergente neutro (NIDN), ácido lático e ácido propiônico aumentaram com a adição do subproduto de manga. Os teores de FDN, FDA e hemicelulose, o $\mathrm{pH}$ e o $\mathrm{N}-\mathrm{NH}_{3}$ (\% do $\mathrm{N}$ total), no entanto, diminuíram com a adição do subproduto de manga. A adição do subproduto de manga teve efeito quadrático sobre os teores de ácido acético e butírico, mas não influenciou a composição em carboidratos totais e nitrogênio insolúvel em detergente ácido (NIDA), que não diferiu entre as silagens. O subproduto de manga pode ser utilizado na ensilagem do capim-elefante, uma vez que adições acima de $8,6 \%$ melhoram o processo fermentativo das silagens. No entanto, essas silagens apresentam baixos níveis de proteína e elevados teores de extrato etéreo e de compostos nitrogenados complexados à fibra (NIDN e NIDA), o que pode comprometer seu aproveitamento pelos animais.
\end{abstract}

Palavras-chave: fermentação, Mangifera indica, Pennisetum purpureum, valor nutritivo

\section{Introduction}

The seasonality of forage production is characterized by a drought period in which the forage material is not available quantitatively or qualitatively for animal nutritional needs. This has led farmers to introduce forage conservation practices on the farms as a way of supplying demand throughout the year. 
Producers have increased silage use because livestock need to be competitive, with reduced costs and increased productivity. Well managed ensilage helps to minimize low productive indexes of regional livestock, favoring rational flock (goats or sheep) herd (cattle or horses) handling in the Brazilian Northeast (Lima \& Maciel, 1998).

Elephant grass (Pennisetum purpureum, Schum.) is very suitable for ensilage, mainly due to high productivity which is, according to Moura (1992) and Faria (1994), $80 \mathrm{t}$ $\mathrm{DM} / \mathrm{ha} \times$ year, when well managed. As the plant grows, the dry matter production increases, but the nutritional value decreases. Thus, ensilage is recommended when there is high productivity per area and good nutritional value, which, according to Lavezzo (1985) and Patel et al. (1967) occurs when elephant grass is harvested after 50 to 60 days of re-growth. Therefore, this grass presents, as a limiting factor, dry matter low content, around 18 to $20 \%$. The dry matter content is a decisive factor in obtaining silages with a good fermentation pattern where, according to Mccullough (1977), the ideal contents should from 28 to $34 \% \mathrm{DM}$.

Using additives in the ensilage alters fermentation, favoring its preservation and increasing its nutritional value (Nússio, et al. 2002).

With the growth of irrigated horticulture in the Brazilian Northeast, several by-products have been tested as silage additions, such as mango. After extracting the mango pulp, $69.4 \%$ are by-products that, after dehydration, can be used as silage addition.

Due to the need to increase the dry matter content of elephant grass forage for ensilage, the by-product, dehydrated mango, can be added to raise the dry matter of the produced silages. The objective of this study was to assess the characteristics of elephant grass silage with the addition of a by-product from mango processing.

\section{Material and Methods}

The experiment was carried out in the Núcleo de Pesquisa em Forragicultura of Departamento de Zootecnia of Universidade Federal do Ceará (UFC), in the municipality of Fortaleza, Ceará.

Five levels of addition of the dehydrated mango (Mangifera indica L.) by-product $(0 ; 4 ; 8 ; 12$ and 16.0\%), based on the natural matter were assessed in elephant grass silage. A randomized complete design with four replications was used.

The experimental silages were made from elephant grass (Pennisetum purpureum, Schum.) from grass pastures established Vale do Curú, in Fazenda Experimental, in Pentecoste, Ceará, belonging to the Universidade Federal do Ceará (UFC). The grass was cut manually at approximately 70 days of age. Soon after it was processed in a forage chopper and [later,] then mixed with the dehydrated mango (Mangifera indica L.) by-product resulting from processing the fruit by extracting the juice and pulp, by the MAISA company in Mossoró, Rio Grande do Norte.

The mango by-product consisted of pressed peels and stones (seed). The by-products were dried in the sun, in a cemented area, spread in layers of approximately seven centimeters thick and turned over at least three times a day to $13 \%-16 \%$ moisture.

At ensilage, the elephant grass presented $19.43 \%$ dry matter (DM), $87.81 \%$ organic matter $(\mathrm{OM}), 5 . .39 \%$ crude protein $(\mathrm{CP}), 77.41 \%$ neutral detergent fiber (NDF), $48.04 \%$ acid detergent fiber (ADF), 29.37\% hemicellulose (HCEL), $3.78 \%$ of ether extract (EE), $78.64 \%$ total carbohydrates (TC), $1.23 \%$ non-fibrous carbohydrates (NFC), 45.38\% neutral detergent insoluble nitrogen (NDIN, \% of total N) and $14.89 \%$ acid detergent insoluble nitrogen (ADIN, $\%$ of total $\mathrm{N}$ ). The dehydrated mango by-product (DMB) presented 94.60\% DM, 94.34\% OM, 6.09\% CP, 61.20\% NDF, 35.15\% ADF, 26.05\% hemicellulose, 5.76\% EE, $82.49 \%$ TC, $21.29 \%$ NFC, 55.87\% NDIN (\%total N) and 20.66\% ADIN (\%total N), based on the dry matter (DM).

Plastic $210 \mathrm{~L}$ drums were used as experimental silos. In each silo, $126 \mathrm{~kg}$ forage were placed and compacted by men to a density of $600 \mathrm{~kg} / \mathrm{m}^{3}$. After weighing and homogenizing the elephant grass with the DMB, the material was compacted inside the silo. The silos were closed with plastic canvases and [shut] sealed with rubber bands.

After 58 days, the silos were opened and some $300 \mathrm{~g}$ homogeneous samples were removed from the silage and stored in the freezer at $-10^{\circ} \mathrm{C}$ until the time for the chemical analyses. The samples were removed from the upper, medium and lower third of the drums and thoroughly homogenized.

In the Laboratório de Nutrição Animal of Departamento de Zootecnia at UFC, the samples were pre-dried in a forced air circulation chamber at $55^{\circ} \mathrm{C}$ and ground in a mill with a sieve with $1 \mathrm{~mm}$ diameter meshes, to determine the DM, OM, CP, NDF, ADF, EE, NDIN (\%total N), ADIN (\%total $\mathrm{N}$ ), according to the methodology described by Silva \& Queiroz (2002). The TC values were obtained by difference, according to the methodology described by Sniffen et al. (1992), in which TC $(\%)=100-(\% C P+\% E E+$ $\%$ ashes). The NFC contents were calculated by the difference between TC and NDF, according to Hall (2001). 
The $\mathrm{pH}$ value was determined according to Silva \& Queiroz (2002) and the $\mathrm{N}-\mathrm{NH}_{3}$ content (\%total N) was determined following the methodology adapted by Cândido (2000) based on the methodologies proposed by Vieira (1980) and Bolsen et al. (1992).

To determine the organic acids, the silage juice was collected by a hydraulic press. Fifty $\mathrm{mL}$ juice was collected and placed in recipients containing $10 \mathrm{~mL} 25 \%$ orthophosphoric solution that after covering were placed in a freezer at -10 ${ }^{\circ} \mathrm{C}$, for subsequent analyses.

The concentrations of organic acids (lactic, acetic, propionic and butyric) were determined in the Laboratório de Polímeros of Departamento de Química Orgânica e Inorgânica of Centro de Ciências at UFC. After the samples were defrosted, approximately $5 \mathrm{~mL}$ were transferred to $10 \mathrm{~mL}$ centrifuge tubes (Sigma Laboratory Centrifuges 4k15) and centrifuged at $5.000 \mathrm{rpm}$ at $10^{\circ} \mathrm{C}$ for 15 minutes. The organic acids were determined by high efficiency liquid phase chromatography (HPLC), according to methodology described by Mathew et al. (1997), by filtering approximately $2 \mathrm{~mL}$ of the supernatent of each sample of the silage juice in cellulose acetate membrane with $0.45 \mu \mathrm{m}$ porosity.

The HPLC were analyzed using a Phenomenex column, Rezex $8 \mathrm{~m} \mu 8 \% \mathrm{H}^{+}$, with $300 \mathrm{~mm}$ long and $7.8 \mathrm{~mm}$ wide, $\mathrm{H}_{2} \mathrm{SO}_{4}$ to $8 \mathrm{mM}$ aqueous solution solvent and of $0.5 \mathrm{~mL} /$ minute elution rate. The equipment was gauged by injection of solutionpatterns containing 10-50 $\mathrm{mM}$ lactic acid/L, 10-60 $\mathrm{mM}$ acetic $\mathrm{acid} / \mathrm{L}, 15-150 \mathrm{mM}$ propionic acid and 10-50 $\mathrm{mM}$ butyric acid, where the standards were also filtered through cellulose acetate membrane with $0.45 \mu \mathrm{m}$ porosity. The concentration peaks of organic acids of the silage juice samples were obtained from their areas in relation to the calibration curve for each pattern injected, using the software Origin 6.0 Professional.

The obtained data was initially analyzed to meet the normality presuppositions, addibility and homoscedasticity.
The data obtained for EE, $\mathrm{N}-\mathrm{NH}_{3}(\%$ total $\mathrm{N})$, butyric acid and propionic acid were transformed to $\left(\mathrm{EE}^{2}\right),\left(\log _{10} \mathrm{~N}-\mathrm{NH}_{3}\right)$, (butyric acid +1 ) and (propionic acid +1 ), respectively, for the regression analysis.

The models were chosen based on the significance of the linear and quadratic coefficients, by the Student $t$ test at the levels of 1 and 5\% probability. As auxiliary tool to the statistical analyses, PROC REG procedure of the SAS Software (2001) was adopted.

\section{Results and Discussion}

The addition of $\mathrm{DMB}$ raised the contents of $\mathrm{DM}$ contents of the silages $(\mathrm{P}<0.01)$ and for each $1 \%$ of DMB added, the DM contents increased by 0.49 percentile points (Table 1 ). This result was expected because the DM contents of DMB (94.6\%) were much higher than the DM contents of the elephant grass $(19.43 \%)$ and therefore its addition should increase the DM contents of the silages.

A similar result was obtained by Gonçalves et al. (2004) who observed [elevations] increases of 0.50 percentile points for each $1 \%$ of guava by-product added to elephant grass silage. Pompeu et al. (2006.) worked with increasing levels of pineapple by-product in elephant grass silages and verified increase in the DM contents of 0.71 percentile points for each $1 \%$ of the by-product.

The minimum level suggested by McDonald (1981) to minimize clostridium fermentations, $30 \% \mathrm{DM}$, was not reached in any of the studied treatments. However, with the addition of $16 \%$ DMB the DM $(27.02 \%)$ content increased considerabl, which resulted in an improvement in the fermentative conditions.

It is important to point out that the effect of the increase in the silage dry matter contents on the growth of clostridium bacteria does not only occur after the above-mentioned levels

Table 1 - Chemical composition of elephant grass silages with increasing levels of addition of dehydrated mango by-product (DMB)

\begin{tabular}{|c|c|c|c|c|c|c|c|c|}
\hline & \multicolumn{5}{|c|}{ Addition level (\%) of DMB } & \multirow[t]{2}{*}{ Regression } & \multirow[t]{2}{*}{$\mathrm{R}^{2}$} & \multirow[t]{2}{*}{$\mathrm{CV}(\%)$} \\
\hline & 0 & 4 & 8 & 12 & 16 & & & \\
\hline Dry matter (\%) & 18.97 & 22.12 & 22.73 & 23.60 & 27.98 & $\widehat{\mathrm{Y}}=19.18+0.49 \mathrm{x} * *$ & 0.71 & 7.80 \\
\hline Crude protein $(\%)$ & 5.16 & 5.61 & 5.73 & 6.13 & 6.21 & $\widehat{\mathrm{Y}}=5.24+0.06 \mathrm{x} * *$ & 0.82 & 3.08 \\
\hline $\begin{array}{l}\text { Neutral detergent } \\
\text { fiber }(\%)\end{array}$ & 74.25 & 73.17 & 70.87 & 67.21 & 65.77 & $\hat{\mathrm{Y}}=74.84-0.57 \mathrm{x} * *$ & 0.86 & 1.87 \\
\hline $\begin{array}{l}\text { Acid detergent } \\
\text { fiber }(\%)\end{array}$ & 48.89 & 48.36 & 47.13 & 45.08 & 43.12 & $\widehat{\mathrm{Y}}=49.48-0.37 \mathrm{x} * *$ & 0.88 & 1.66 \\
\hline Hemicellulose (\%) & 25.36 & 24.80 & 23.74 & 22.13 & 22.65 & $\widehat{\mathrm{Y}}=25.36-0.20 \mathrm{x} * *$ & 0.52 & 4.64 \\
\hline Ether extract $(\%)$ & 2.80 & 3.42 & 4.05 & 4.78 & 5.78 & $\left(\mathrm{EE}^{2}\right)(\mathrm{v})=0.12-0.006 \mathrm{x} * *$ & 0.92 & 14.12 \\
\hline Total carbohydrates $(\%)$ & 78.93 & 78.56 & 79.21 & 78.81 & 77.85 & $\hat{\mathrm{Y}}=78.67 \pm 0.64$ & - & 0.81 \\
\hline $\begin{array}{l}\text { Non-fibrous } \\
\text { carbohydrates }(\%)\end{array}$ & 4.67 & 5.39 & 8.34 & 11.60 & 12.08 & $\widehat{\mathrm{Y}}=4.21+0.52 \mathrm{x} * *$ & 0.82 & 16.69 \\
\hline NDIN (\% $\mathrm{N}$ total) & 35.43 & 41.04 & 43.25 & 39.15 & 43.96 & $\hat{\mathrm{Y}}=37.53+0.38 \mathrm{x} * *$ & 0.31 & 7.65 \\
\hline ADIN ( $\% \mathrm{~N}$ total $)$ & 21.80 & 22.38 & 22.69 & 21.84 & 21.46 & $\widehat{Y}=22.03 \pm 1.19$ & - & 5.38 \\
\hline
\end{tabular}

$* *(\mathrm{P}<0.01)$.

$\mathrm{NDIN}=$ neutral detergent insoluble nitrogen $(\% \mathrm{~N}$ total $)$; and ADIN $=$ acid detergent insoluble nitrogen $(\% \mathrm{~N}$ total $)$. 
were reached. According to Muck (1988), with the increase in the DM contents the water activity decreases progressively, causing proportional reduction in microorganism growth, especially those of the Clostridia genus. Thus, the addition of DMB favors the fermentative process even when the DM contents taken as ideals are not reached.

An increase in the CVP contents of the silages with the addition of DMB (Table 1) was still observed. For each $1 \%$ DMB added, the CP contents of the silages increased by 0.06 percentile points. In spite of this increase, the $\mathrm{CP}$ contents of the silages were not enough to reach the minimum 7\% content, desirable for the good operation of the rumen, which can be explained by the low CP content of the DMB (6.09\%). Thus it was observed that such silage, if supplied alone to the ruminants, will have a limited nutritive value because it will limit the ruminant fermentation and consequently the nutrient intake and digestibility.

The results were in agreement with those obtained by Gonçalves et al. (2004) and Ferreira (2005) who, by when working with levels of addition of guava and pineapple byproducts in elephant grass ensilage, respectively, observed [elevations] increases in the $\mathrm{CP}$ content, but the minimum concentration of $7 \%$ was not reached.

The NDF contents decreased linearly $(\mathrm{P}<0.01)$ with the addition of DMB (Table 1). For each $1 \%$ of addition of DMB, a decrease of 0.57 percentile points in the NDF of the silages, that can be explained by the smallest NDF content (61.20\%) of the DMB compared to elephant grass (77.41\%). The reduction in the NDF contents with the addition of DMB to the elephant grass silages, separately, can improve the DM consumption of the silages, because decreases in the NDF contents of the feed improve DM intake (Resende et al., 1994). However, although this increase in intake can happen, it is important to remember that other factors interact to determine the DM intake of a compound feed including the low $\mathrm{CP}$ contents as commented above, and the high EE contents that can minimize or even neutralize the beneficial effect of the decrease in the NDF contents.

The ADF and hemi cellulose contents also decreased linearly $(\mathrm{P}<0.01)$ with the addition of DMB (Table 1$)$. To each $1 \%$ of DMB added, the ADF and hemicellulose contents of the silages decreased by 0.37 and 0.20 percentile points, respectively. For ADF, the decrease was already expected because the DMB presents contents of $35.15 \%$ and elephant grass, $48.04 \%$. Thus, the addition of DMB would naturally lead to a reduction in that component.

The hemicellulose contents in the silages, however, were not only inferior to the elephant grass but also to the DMB pre-ensilage. The justification for this fact is that hemicellulose can be used as substratum for fermentation by the microorganisms and consequently presents lower values than the materials originally ensilaged. According to Henderson (1993), up to $40 \%$ of the hemicellulose present in the forages can be used during the silage fermentative process. Also McDonald (1981) mentioned that hydrolysis of the hemicellulose can occur through the action of bacterial hemicellulase and/or by hydrolysis by organic acids produced during the silage fermentation.

Sá et al. (2007) and Gonçalves et al. (2006) worked with elephant grass silages with the addition of processed mango and annatto by-products and produced reductions in the ADF content of 0.24 and 0.81 percentile points for each $1 \%$ of addition of mango and annatto by-products, respectively.

There was an increase $(\mathrm{P}<0.01)$ of 0.18 percentile points in the $\mathrm{EE}$ content of the silages for each $1 \%$ of DMB added (Table 1), that can be associated partly to the larger EE content $(5.76 \%)$ of DMB. It is important to point out that the EE contents in the silages reached levels that can inhibit forage intake. The levels rose to $2.80 \%$ in the untreated elephant grass silages by $5.78 \%$ with an addition of $16 \%$ DMB. This level was greater than that recommended by Palmquist (1994) who suggested that $5 \%$ would be the maximum EE limit for the diets based on compound feed.

Differences were not verified $(\mathrm{P}>0.05)$ in the TC contents of the silages in function of the level of addition of DMB (Table 1) and an average value of $78.67 \%$ was obtained. Although the TC content of the DMB (82.49\%) was superior to the elephant grass $(78.64 \%)$ ensilage, it was observed that with an addition of up to $16 \%$ there was no alteration in the TC contents of the silages. This is justified by the fact that part of the soluble carbohydrates can be used in the silage fermentative process.

There was an increase for $\mathrm{NFC}(\mathrm{P}<0.01)$ of 0.52 percentile points for each $1 \%$ DMB (Table 1), that can be associated to the larger NFC content (21.29\%) of the DMB. The NFC can serve as substratum for the bacteria of the Lactobacillus genus to improve the silage fermentation (Ferreira et al.2004), as well as, if present in high levels, to increase the intake, digestibility and energetic density of the silage.

Linear increase $(\mathrm{P}<0.01)$ was observed in the NDIN contents (\%total $\mathrm{N})$ when DMB was added the silages (Table 1), estimating an increase of 0.38 percentile points for each $1 \%$ of addition of DMB, which can be explained by the larger NDIN content (\%total N) of the DMB (55.87\%) compared to the elephant grass $(45.38 \%)$ at ensilage. However, the NDIN contents (\%total N) of the silages were lower than the NDIN contents ( $\%$ total $N$ ) of the DMB and the elephant grass, that can be related to the action of the enzymes produced during ensilage on the nitrogen linked 
to NCF. According to Van Soest (1994) the NDIN can present considerable digestibility, but this nitrogen presents slower rates of digestion. Certainly, the slow $\mathrm{N}$ availability allied to the below-the-recommended content $(7 \% \mathrm{CP})$ will limit the use of these silages.

Variations were not observed $(\mathrm{P}>0.05)$ in the ADIN contents (\%total $\mathrm{N})$ in the elephant grass silages with the addition of DMB (Table 1), and the mean content was $22.03 \%$. In spite of observing different ADIN contents $(\%$ total $\mathrm{N})$ in the DMB $(20.66 \%)$ and elephant grass $(14.89 \%)$ at ensilage, the ADIN values ( $\%$ total $\mathrm{N})$ of the silages were greater than those of the DMB and the elephant grass, which showed there was a heating problem in the silages. Heating in silages sharply reduces the protein digestibility due to the increase in the ADIN contents (\% total N), which is unavailable for the microorganisms of the rumen (Van Soest, 1994).

The $\mathrm{pH}$ values were influenced by the levels of DMB addition (Table 2). The increase of $1 \%$ in DMB provided a reduction of 0.01 units in the $\mathrm{pH}$ value of the silages. The $\mathrm{pH}$ of all the studied silages was considered appropriate for good fermentation. However, the $\mathrm{pH}$ value is a parameter of little importance when evaluated separately, because for a silage to be considered of good quality the $\mathrm{pH}$ must decrease quickly so that the $\mathrm{N}-\mathrm{NH}_{3}(\%$ of total $\mathrm{N})$ and butyric acid contents do not increase (Whittenbury et al., 1967).

The data obtained in the present study corroborated with the observations by Whittenbury et al. (1967) because, although the $\mathrm{pH}$ was maintained within the ideal range in all the silages, the $\mathrm{N}-\mathrm{NH}_{3}$ contents $(\%$ total $\mathrm{N})$ were high ( $>12 \%$ total nitrogen) in the untreated elephant-grass silages and it only reached levels lower than the recommended with the inclusion of more than $8.6 \% \mathrm{DMB}$. According to the regression equation, there was a decrease of 0.91 percentile points for each $1 \%$ of addition of DMB. Contents of $\mathrm{N}-\mathrm{NH}_{3}(\%$ total $\mathrm{N})$ greater than $12 \%$ (McDonald, 1981) indicate protein degradation, causing losses of nutrients and production of low quality silages.
An increasing and linear effect was observed $(\mathrm{P}<0.01)$ with the addition of DMB (Table 2) on the lactic acid contents of the silages and an increment of 0.14 percentile points lactic acid for each $1 \%$ of addition of DMB was estimated. According to Roth \& Undersander (1995), silage is considered of good quality when it presents lactic acid content between 4 and $6 \%$. In this case, it was verified that the $4 \%$ lactic acid content was reached with the addition of $8.6 \% \mathrm{DMB}$ to the silages. It is important to point out that the level of addition of DMB that allowed lactic acid production, characteristic of good silages, coincided with the level that maintained the $\mathrm{N}-\mathrm{NH}_{3}$ levels ( $\%$ total $\mathrm{N}$ ) below the critical level, which indicated the occurrence of intense proteolysis during fermentation.

The regression analysis revealed a quadratic effect for the acetic acid content $(\mathrm{P}<0.01)$ and a maximum content of $0.66 \%$ of acetic acid was obtained after adding $11.25 \%$ DMB (Table 2). The acetic acid originates from fermentations by enterobacteria, heterofermentative lactic bacteria and Clostridium (Jobim \& Gonçalves, 2003) and the acetic acid values obtained in this research were considered low and appropriate for well conserved silages, according to Roth \& Undersander (1995).

The addition of DMB raised the propionic acid contents of the silages ( $\mathrm{P}<0.01)$. For each $1 \%$ of inclusion an increase of 0.02 percentile points was observed in the propionic acid contents (Table 2). According to Roth \& Undersander (1995), for a silage be considered of good quality it should present a propionic acid content lower than $0.5 \%$ and all the silages were considered well preserved for this parameter.

Quadratic effect was observed for the butyric acid content of the silages $(\mathrm{P}<0.01)$ with a maximum content of $0.46 \%$ butyric acid for the $8.5 \%$ DMB level (Table 2). However, after this level, the butyric acid content decreased. When the butyric acid values of the silages were estimated, only the addition of $16 \%$ DMB $(0.08 \%)$ was enough to produce silage with butyric acid content lower than $0.1 \%$, which characterizes a good quality silage.

Table 2 - The $\mathrm{pH}$ and the contents of ammoniacal nitrogen $\left(\mathrm{N}-\mathrm{NH}_{3} \%\right.$ total $\left.\mathrm{N}\right)$, lactic, acetic, propionic and butyric acid of elephant grass silages with [growing] increasing levels of addition of dehydrated mango by-product - DMB

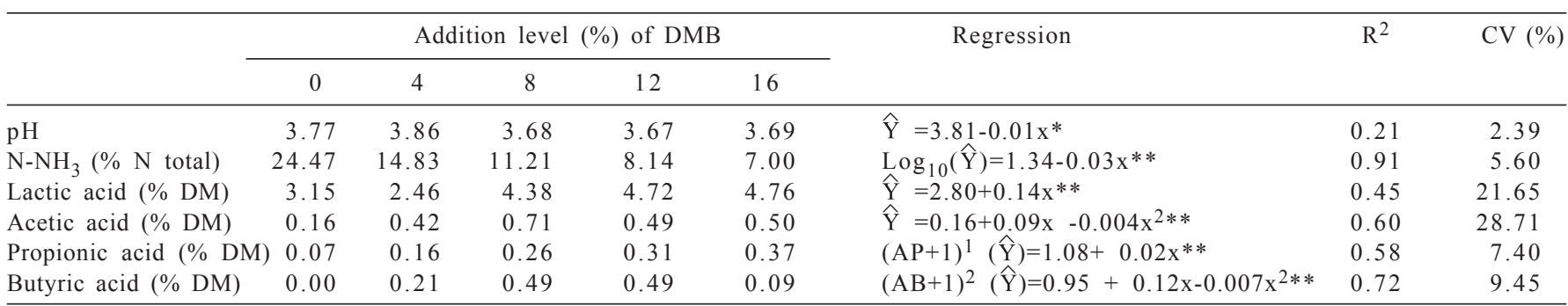

$*(\mathrm{P}<0.05) . * *(\mathrm{P}<0.01)$

3 - $\%$ of dry matter. 
The increase in the butyric acid contents to the level of $8.5 \%$ of addition of DMB proved that the addition of absorbent materials has an important function in the silage fermentative process. The results obtained in the present study show that with the addition of DMB at elephant grass ensilage, at a level higher than $8.6 \%$, promotes an improvement in the fermentative process because it optimizes the $\mathrm{N}-\mathrm{NH}_{3}(\%$ total $\mathrm{N})$, lactic and butyric acid contents.

\section{Conclusions}

The by-product of mango processing can be used in elephant grass ensilage, because additions of over $8.6 \%$ improve the silage fermentative process. However, it should be considered that such silages present low protein levels and high etherl extract contents as well as nitrogen compound mixed with the fiber (NDIN and ADIN), which can compromise their use for an animal nutrition.

\section{References}

ANDRADE, J.B.; LAVEZZO, W. Aditivos na ensilagem de capimelefante. II. Qualidade das silagens amostradas por dois métodos. Pesquisa Agropecuária Brasileira, v.33, n.11, p.1873-1882, 1998 .

BOLSEN, K.K.; LIN, C.; BRENT, B.E. et al. Effect of silage additives on the microbial succession and fermentation process of alfafa and corn silages. Journal of Dairy Science, v.75, p.3066-3083, 1992 .

CÂNDIDO, M.J.D. Qualidade e valor nutritivo de silagens de híbridos de sorgo (Sorghum bicolor (L.) Moench) sob doses crescentes de recomendação de adubação. 2000. $55 \mathrm{f}$. Dissertação (Mestrado em Zootecnia) - Universidade Federal de Viçosa, Viçosa, MG.

FARIA, V.P. Técnicas de produção de silagens. In: PEIXOTO, A.M.; MOURA, J.C.; FARIA, V.P. (Eds.). Pastagens: fundamentos de exploração racional. Piracicaba: Fundação de Estudos Agrários Luiz de Queiroz, 1994. p.695-719.

FERREIRA, A.C.H.; NEIVA, J.N.M.; RODRIGUEZ, N.M. et al. Valor nutritivo das silagens de capim-elefante com diferentes níveis de subprodutos da indústria do suco de caju. Revista Brasileira de Zootecnia, v.33, n.6, p.1380-1385, 2004.

FERREIRA, A.C.H.; NEIVA, J.N.M.; RODRIGUEZ, N.M. et al. Avaliação nutricional do subproduto da agroindústria de abacaxi como aditivo de silagem de capim-elefante. Revista Brasileira de Zootecnia, v.38, n.2, p.223-229, 2009.

GONÇALVES, J.S.; NEIVA, J.N.M.; CÂNDIDO, M.J.D. et al. Composição bromatológica e características fermentativas de silagens de capim-elefante (Pennisetum purpureum Schum.) cv. Roxo contendo níveis crescentes do subproduto da semente de urucum (Bixa orellana L.). Revista Ciência Agronômica, v.37, n.2, p.228-234, 2006.

GONÇALVES, J.S.; NEIVA, J.N.M.; VIEIRA, N.F. et al. Valor nutritivo de silagens de capim-elefante (Pennisetum purpureum Schum.) com adição de diferentes níveis dos subprodutos do processamento de acerola (Malpighia glabra L.) e de goiaba (Psidium guajava L.). Revista Ciência Agronômica, v.35, n.1, p.131-137, 2004.

HALL, M.B. Recent advanced in non-ndf carbohydrates for the nutrition of lactating cows. In: SIMPÓSIO INTERNACIONAL
EM BOVINOS DE LEITE: Novos conceitos em nutrição, 2., Lavras, 2001. Anais... Lavras: Universidade Federal de Lavras, 2001. p.139-148.

HENDERSON, N. Silage additives. Animal Feed Science Technology, v.45, p.308-317, 1993.

JOBIM, C.C.; GONÇALVES, G.D. Microbiologia de forragens conservadas. In: REIS, R.A.; BERNARDES, T.F.; SIQUEIRA, G.R. et al. (Eds.) Volumosos na produção de ruminantes: valor alimentício de forragens. Jaboticabal: FUNEP, 2003. p.1-26.

LAVEZZO, W. Silagem de capim elefante. Informe Agropecuário, v.11, n.132, p.50-57, 1985

LIMA, G.F.C., MACIEL, F.C. A ensilagem como uma das ferramentas de inserção da pecuária nordestina nos mercados globalizados. In: CONGRESSO NORDESTINO DE PRODUÇÃO ANIMAL. Fortaleza, 1998. Anais... Fortaleza: Sociedade Nordestina de Produção Animal, 1998. p.59-77.

MATHEW, S.; SAGATHEVAN, S.; THOMAS, J. et al. An HPLC method for estimation of volatile fatty acids in ruminal fluid. Indian Journal of Animal Science, v.67, n.9, p.805-807, 1997.

McCULLOUGH, M.E. Silage and silage fermentation. Feedstuffs, v.13, n.49, p.49-52. 1977.

McDONALD, P. The biochemistry of silage. New York: John Willey \& Sons, 1981. 226p.

MOURA, J.C. Capim-elefante. In: MOURA, J.C. et al. (Eds.). Capineiras: capim-elefante, cana-de-açúcar como volumoso para bovinos e cana + uréia na recria de bovinos. Piracicaba: Fundação de Estudos Agrários Luiz de Queiroz, 1992. p.1-6.

MUCK, R.E. Factors influencing silage quality and their implications for management. Journal of Dairy Science, v.71, n.11, p.2992-3002, 1988.

NUSSIO, L.G., PAZIANI, S.F., NUSSIO, C.M.B. Ensilagem de capins tropicais. In: REUNIÃO ANUAL DA SOCIEDADE BRASIleirA DE ZOOTECNIA, 39., 2002. Recife. Anais.. Recife: Sociedade Brasileira de Zootecnia, 2002. p.60-90.

PALMQUIST, D. L. The role of dietary fats in efficiency of ruminants. Conference: regulating lipids metabolism to increase productive efficiency. Journal of Nutrition, v.124, p.1377S1382S, 1994

PATEL, B.M., PATIL, C.A., DHAMI, B.M. Effect of different cutting intervals on the dry matter and nutrient yield of Napier hybrid grass. Indian Journal of Agriculture Science, v.37, p.404-409, 1967.

POMPEU, R.C.F.F., NEIVA, J.N.M., CÂNDIDO, M.J.D. et al. Valor nutritivo de silagens de capim-elefante (Pennisetum purpureum Schum.) com adição de subprodutos do processamento de frutas tropicais. Revista Ciência Agronômica, v.37, n.1, p.77-83, 2006.

RESENDE, F.D.; QUEIROZ, A.C.; FONTES, C.A. et al. Rações com diferentes níveis de fibra em detergente neutro na alimentação de bovídeos em confinamento. Revista Brasileira de Zootecnia, v.23, n.3, p.366-376, 1994.

ROTH, G.; UNDERSANDER, D. Silage additives. In: ____ (Eds.) Corn silage production management and feeding. Madison: Madison American Society of Agronomy, 1995. p.27-29.

SÁ, C.R.L.; NEIVA, J.N.M.; GONÇALVES, J.S. et al. Composição bromatológica e características fermentativas de silagens de capim elefante (Pennisetum purpureum Schum.) com níveis crescentes de adição do subproduto da manga (Mangifera indica L.). Revista Ciência Agronômica, v.38, n.2, p.199-203, 2007.

SILVA, D.J.; QUEIROZ, A.C. Análise de alimentos: métodos químicos e biológicos. 2.ed. Viçosa, MG: Universidade Federal de Viçosa, 2002. 165p.

SNIFFEN, C.J.; O'CONNOR, J.D.; VAN SOEST, P.J. A net carbohydrate and protein system for evaluating cattle diets: II. Carbohydrate and protein availability. Journal of Animal Science, v.70, n.11, p.3562-3577, 1992. 
STATISTICAL ANALYSES SYSTEM - SAS. User's guide. Cary: SAS Institute, 2001. 1028p.

TOSI, P.; MATTOS, W.R.S.; TOSI, H. et al. Avaliação do capimelefante (Pennisetum purpureum Schum.) cultivar Taiwan A-148. ensilado com diferentes técnicas de redução de umidade. Revista Brasileira de Zootecnia, v.28, n.5, p.947-954, 1999.

VAN SOEST, P.J. Nutritional ecology of the ruminant. 2.ed. Ithaca, New York: Cornell University Press, 1994. 476p.
VIEIRA, P.F. Efeito do formaldeído na proteção de proteínas e lipídios em rações para ruminantes. 1980. 98f. Dissertação (Mestrado em Zootecnia) - Universidade Federal de Viçosa, Viçosa, MG.

WHITTENBURY, R; McDONALD, P; BRYAN-JONES, D.J. A short review of some biochemical and microbiological aspects of silage. Journal Science Food and Agricultural, v.18, n.4, p.441-444, 1967. 